\title{
Poetry in the Indonesian Seriosa Composition
}

\author{
Kartini R.M Manalu ${ }^{1}$, Lono Lastoro Simatupang ${ }^{2}$, Nyak Ina Raseuki ${ }^{3}$ \\ kartini.manalu@uhn.ac.id ${ }^{1}$,Lono_simatupang@yahoo.com², \\ nyakraseuki@pascasarjanaikj.ac.id ${ }^{3}$ \\ Study of Performing Arts and Fine Arts Postgraduate School of Gadjah Mada University \\ HKBP University Nommensen, Indonesia ${ }^{1}$, Study of Performing Arts and Fine Arts \\ Postgraduate School of Gadjah Mada University ${ }^{2}$, Creation and Study of Arts \\ Postgraduate School of the Jakarta Institute of Arts, Indonesia ${ }^{3}$
}

\begin{abstract}
Poetry is a series of diverse complex parts of the artistic whole. Putting poetry together after analysis is like coordinating a musical performance; both actual poetry and actual musical composition converge into an artistic experience that grows deeper and deeper we understand it. Seriosa songs, the point is the equality of music and text, a synthesis of art forms from two different media. Those who fail to understand the meaning of poetry will be correlated with failure to understand the real meaning of music. Singers who have not thoroughly studied poetry cannot sing or play seriosa compositions with focus, imagination and vitality. The need to study poetry in preparation for seriosa performances is not an option, but rather becomes a major part of the basic work for seriosa singers and pianists. There is a phenomenon that occurs, especially in music education in Indonesia, they study seriosa songs by prioritizing notation without ever having the opportunity to learn language as art, either in poetry or in the form of prose. We separate poetry discussions into two basic components: poetry content and poetic forms. In addition to general concerns about word usage, we will also examine how words are chosen for language features that suggest the musical arrangement of the verse: words that exploit sound and color. Choosing certain words because their bright or dark sounds convey certain senses or emotions is one of the poet's most dramatic resources, and recognizing these loud and colorful words is of great concern to the composers who arrange poetry and singers who speak texts.
\end{abstract}

Keywords: seriosa, poetry, composition, Indonesian idiom, singer, analysis

\section{Introduction}

Seriosa is a term that still leaves room for debate today, although its use has become common after entering the Indonesian Dictionary (Kamus Besar Bahasa Indonesia, abbreviated KBBI). According to the KBBI, seriosa is a type of rhythm that is taken 
seriously because it requires a higher sound technique, distinguished from the rhythm of keroncong, or the rhythm of entertainment. Even though, if we look at the definition of rhythm, in its primary sense, the wole feeling of movement in music, with the strong implication of both regulary and differentiation. Thus, breathing (inhalation vs. exhalation), pulse (systole vs. diastole), and tides (ebb vs. flow) all are examples of rhythm, (Apel, 1969). This definition is certainly not relevant, does not reflect the material, and the intended seriosa composition concept. Seriosa is not only a matter of rhythm, but far from it, seriosa is related to the style of singing, vocal techniques, composition (poetry and musical accompaniment) that form a single unified whole.

To see the extent to which seriosa has been investigated by previous researchers, the author has conducted a literature review, and from there, the author found several studies that have been discussed related to seriosa. However, these researchers are more likely to examine seriosa in the context of history and seriosa music performances. Some of them are; Mohammed, who in his dissertation said that the seriosa song was the most important nationalistic song genre in Indonesia in the 1950s and 1960s, and became the main attraction of the national annual singing competition, namely: Bintang Radio Indonesia. This research was conducted to investigate how the development of seriosa and why this genre mimics art songs in Europe, and became so famous in Indonesia. The purpose of this study is twofold; to distinguish the role of genre that led to its growth as a nationalist song in Indonesia, and to investigate the use of folk songs in music to promote nationalism. As a genre that promotes Indonesian national identity, seriosa has lost its popularity due to the rise of Indonesian popular music in the 1970s. This dissertation examines aspects of the history of seriosa songs as part of the reflection of national music and the development of seriosa. The writer's criticism of this dissertation lies in the understanding of researchers who consider seriosa an imitation of an art song in Europe without showing an in-depth study of seriosa work in which the location and citation material.

Tjaroko, in his thesis said that German lied is a vocal musical composition, has three song forms: strophic, through-composed and song cycle. Entering Indonesia, brought by the Dutch in the 16th century. Its existence inspires Indonesian songwriters, thus affecting the birth of the seriosa. Seriosa songs are Indonesian vocal music compositions, as an adaptation of German lied. Born in Indonesia in the 1930s, pioneered by Cornel Simanjuntak. Seriosa songs contain nuances of the archipelago music, and Indonesian music idioms. Loaded with cultural contents, historical, and the value of Indonesian nationalism has made it a distinctive song of Indonesia, and a music genre in Indonesia. Ups and downs of the history of the development of 
seriosa songs, strongly influenced by developments in the political, social and technological situation in Indonesia. In this case the government policy at certain times, the condition of music education, the development of application of music technology and electronic media influenced it. Seriosa songs are still an effective media for vocal music learning in higher education as well as public and private music schools. There is an artistic content that is characteristic of Indonesia and its sound production technique uses two German and Italian singing styles. Until now, the song seriosa is still present in classical music performances, although it does not become the main dish. Seriosa songs give priority to artistic value and not financial value. Tjaroko's research places more emphasis on historical aspects and the development of seriosa.

Tuutau, doing research on the existence of seriosa in the present, and seriosa is called the Indonesian classical vocal music. The purpose of this research is to create a better understanding, and greater interest in the vocal genre by tracing its origins through the socio-political context of national history. The discussion begins by saying that the seriosa song is an important element in the independence movement from the Dutch colonial power. The anti-communist movement at the end of the 20th century also led to execution or expulsion of most seriosa composers, and this genre of music then suffered a major setback for decades. Tuutau mentioned that the composer Ananda Sukarlan, acknowledging the lack of Indonesian classical music in the early 2000s and this situation led him to start writing for vocal compositions. The work "Tembang Puitik" is an example of how Ananda Sukarlan tried to change the public's view of classical music to the public. This dissertation tries to look at seriosa in a different perspective, Tuutau stepped in to see the composition of the song seriosa in the hands of composer Ananda Sukarlan with a more virtuoso touch. The experience and inspiration from composers' songs such as Franz Schubert and Gustav Mahler have contributed to Ananda Sukarlan drive to create music. The work "Tembang Puitik" is a poetic song based on poetry and divided into sections.

Yunita, saw seriosa as a nationalism movement developing in Europe in 1830 and spread to various countries in the world including in Indonesia. European nationalism movement in its development gave a great influence on the development of nationalism in the Asia-Africa region, especially in Indonesia and developments in the history of music. The nationalism movement in music began in Russia and then followed by the nationalism movement in the Scandinavian countries, Spain, Italy, Hungary, Britain and the United States. European nationalism influenced several composers in creating their music. They incorporate elements of melody and poetry that are in accordance with folk music and which are well known to their society. In Indonesia, nationalism made Indonesian composers create songs with the aim of 
fueling the spirit of struggle to break away from invaders. Some Indonesian composers at that time, among others, W.R. Supratman, Kusbini, Ismail Marzuki and Cornel Simanjuntak. Seriosa songs composed by Indonesian composers have a big role to play in the struggle for independence. Seriosa songs created using Western musical sciences such as diatonic scales, harmony, song structure, rhythmic structures, etc., are the result of musical influences from the west.

Based on this literature review, the authors see that there is space that has not been touched by previous researchers, and this is worthy of further research. Some of them are; (1) when seriosa is called an imitation of a lied or art song, then the question arises to what extent is the element imitated in the composition of seriosa? or song seriosa not an imitation of a lied work and an art song? (2) at present, seriosa is not only seen as a work for nationalistic movements, therefore, the seriosa category in terms of thematic matters is interesting to study; and (3) how poetry becomes an important material in composing works of seriosa composition. In this research, the writer will limit the problem formulation to the third point.

\subsection{Significance of the study}

The results of this study will be particularly useful for singers, and vocal students who are studying seriosa, both in vocational high schools (Sekolah Menengah Kejuruan, abbreviated SMK) and also in universities that open music programs. They will find out how to sing good seriosa, not only able to master notation well, but other important elements, such as poetry, are an important part of the seriosa composition. In addition to the singers, the findings in this study can also be used as music analysis material and musical composition. Thereby encouraging students to be able to compile serial work. The lack of seriosa composition is inseparable from the role of educational institutions in Indonesia which have not given attention and appreciation for the work of the nation itself, so that we give more time only to discuss works of compositions originating from the West.

\subsection{Scope and Limitation of the study}

Each study certainly can not be separated from the limitations or scope to be studied, this happens because of the time and also the costs required. Therefore, this research is limited to the seriosa song by Cornel Simanjuntak. 


\section{Research Design And Methodology}

In general, this study uses a qualitative research design. The author will conduct an analysis of a seriosa composition entitled "O Ale Alogo" by Cornel Simanjuntak using a musicology approach. The author separates poetry discussion into two basic components, namely poetry content and poetry form. The content of poetry is related to imaging, metaphor, parable, symbol, irony, word play, and personification; while the poetic form is more about meters, rhyme schemes, and stanza division.

\section{Findings And Conclusions}

Cornel Simanjuntak was born in Pematangsiantar, North Sumatra in 1921. He is considered an Indonesian composer who pioneered the creation of seriosa compositions. His music education was under the guidance of Jesuit J. Schouten when he attended the HIK Xaverius College Teacher Training School in Muntilan, Central Java. Some of his compositional works show creativity in the power of beautiful melodies, seen from the works "Mekar Melati" and "Mari Berdendang". The works "Kemuning" and "O, Angin" were composed with touching lyrics and contained dramatic tastes. Some other compositions are "Maju Tak Gentar", "Tanah Tumpah Darah", "Padamu Pahlawan", "Teguh Kukuh Berlapis Baja", "Indonesia Tetap Merdeka" and "Sorak-Sorak Bergembira". During the Japanese occupation, Cornel created many compositional works that were full of the meaning of propaganda, including "Menanam Kapas", "Menabung", "Bekerja", "Bikin Kapal", and "Hancurkanlah Musuh Kita". Other composition works are "Citra", "O Ale Alogo", "Kupinta Lagi”, “Andigan ma”, and "Di na laho Maridi” (Manalu, 2014).

The hallmark of Cornel's composition lies in the use of poetry in seriosa compositions. The inclusion of poetry in seriosa can be seen as a new breakthrough in the world of composition in Indonesia. However, poetry and music are two different characters. Poetry is related to the senses, and music is related to the heart or soul. Music seems to be placed at a lower level, so it must be combined with the addition of poetry. Besides Cornel, we can also find out how Wagner treats music with poetry. Wagner held fast to the principle of lifting poetry by lowering music, must produce something great from instrumental music. John Hinton defines this principle by saying that the poem, or to speak accurately, poetic ideas, have two interpretations - proper poetry and music, but poetry and music are two different things, which are, when combined, produces the highest advantage, (Field, 1874). 
Another composer who uses poetry in musical compositions is Beethoven, this is seen in the composition of the ninth symphony finale movement. Beethoven made a new breakthrough in the preparation of symphonies by ignoring the rules that are already common (Simanjuntak, 2014; 2018). There have been attempts where dramatic musical instrumental characters have ever been made, and Beethoven has reached the limits of his own strength, so use poetry to achieve its goals. It is clear how the words in poetry are an important part of musical expression, even leading to perfection, becoming a stepping stone towards the further development of poetic music, as we see in what is commonly called 'the music of the future' (Bennett, 1874).

In the context of seriosa, Cornel uses poetry in composition to convey various metaphors for the listener. The use of this poem will certainly correlate with consideration of melody, rhythm, tempo, accompaniment, scale, and sound color. These aspects will be analyzed specifically in the seriosa work entitled "O Ale Alogo" by Cornel Simanjuntak.

\subsection{Poetry Representation}

According to Webster, the word "rhetoric" connotes "the art of using words effectively ... to influence or persuade ... including the use of figures of speech". A "figure of speech" is in turn defined as "an expression that uses words in an unusual sense to provide beauty or clarity of style; [including usage] metaphors, personifications, parables..." Poetry, among other things, is the art of speaking rhetorically, to express thoughts and feelings in unusual terms - smooth, sweet, provocative, intense. Poets enhance expression with the most common rhetorical device: pictures and symbols. In general, an image is a representation of something that makes an idea clearer and places the idea in a rich and expressive context. In addition, the image of a poem also connotes a choice of arrangement and detailed description that further dramatizes poetic meaning. Another term related to poetry that is often considered synonymous with "image" is a symbol. And although the two terms basically refer to the same thing, symbolic representations are often more abstract. For example, bird song generally connotes images of living natural sounds, the song of a nightingale is a true symbol of lamentation for the loss of love.

"O Ale Alogo" is a short poem from Cornel which describes an area surrounded by high mountains and wide waters. Cornel uses abstract metaphors to bring us to an area in western Indonesia. There are three symbols used in this poem, 
namely: mountains, sea and wind which represent the area around Lake Toba.

$O$ ale alogo $(a)$

Boanma tonanghon $(b)$

Tu haholongan $(b)$

Taripar dolok na timbo $(b)$

Taripar laut natimbo (a)

Sahat tu huta na dao (a)

$O$ ale alogo $(a)$

Aha didok ho (b)

Tung mansai uli baritami (c)

Lake Toba is surrounded by high mountains and the area is inhabited by 7 Regencies (Simalungun, Toba Samosir, Tapanuli Utara, Humbang Hasundutan, Dairi, Karo, and Samosir.)

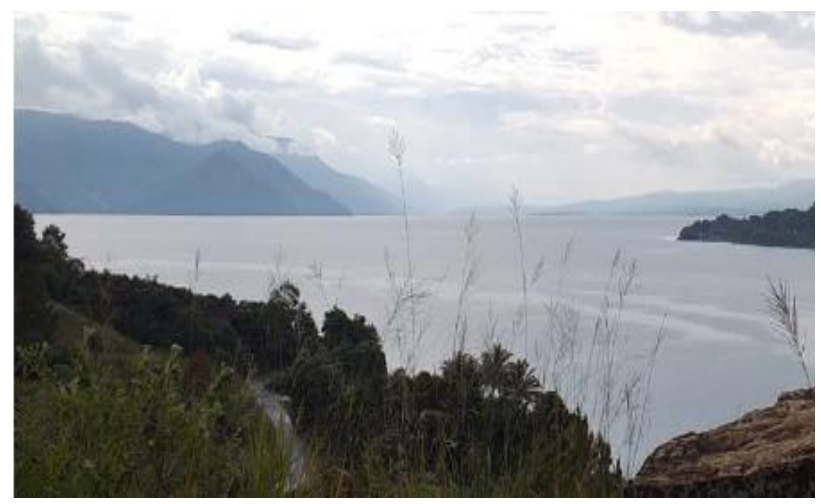

Figure 1. Lake Toba, the position of the picture taken in the Muara area.

The work "O Ale Alogo" was done in the period 1940s, at that time Indonesia was still in the colonial period towards independence. Communication between regions is still very limited and the conditions are not as we have experienced this time (can be via telephone and social media). Cornel tries to convey a message through alogo (wind) to her lover who lives in a remote area. Cornel also hopes for a reply from the message he conveys. In this position, we are faced with two views. First, Cornel tries to make a figure of speech to illustrate 
the beauty of Lake Toba with continuous wind movements that run continuously. In fact, when the author was at the location of Lake Toba (April 2019), precisely the mountains around the Muara area. The author can feel how beautiful the view of Lake Toba and also the movement of the wind 'soft', makes us want to be there for a long time. Second, Cornel wants to pour out feelings towards her lover who is far from her life. Cornel wanted to illustrate the obstacles experienced through the metaphor of high mountains and vast waters. The wind is a symbol that can help it in solving the problems it faces. As researchers, we continue to provide space for subsequent researchers to provide other interpretations from the two perspectives already explained.

\subsection{Poetry Forms}

Poetry is divided into sections called stanzas (sometimes called "strophes".) Couplets are two-line poetry units; it can consist of complete stanzas, or can be put into larger stanzas. The three-line stanza is called tercet, the four-line stanza is a quatrain, and the five-line stanza, a cinquain. Based on the arrangement of the stanzas in "O Ale Alogo", this poem is included in a three-line stanza. The length of the lines in the stanza varies greatly, and the difference in length of the lines also contributes to the meaning of the poem. Shorter lines tend to be clearer and to convey their content more concisely, with fewer elements. Conversely, longer lines of poetry convey more information and can express a number of things such as luxury or excitement. The length of the poetic line directly affects the composer's arrangement, and the short or long vocal phrases that are produced are accompanied by other musical elements that help to convey the shortness of poetic sensitivity or extension.

\subsection{Musical Analysis}

This section is a step to seeing the considerations that Cornel uses when placing poetry in musical compositions. Of course you will see the relationship between syllables with melody, intervals, harmony and accompaniment. The work "O Ale Alogo" begins with an intro of 2 bars along the F-Dm7-F-Dm7 chords at 5P intervals $(\mathrm{F}$ and $\mathrm{C})$ on the $\mathrm{F}$ key (the pattern is repeated in a relatively long time), describe the movement of the wind with a moderate tempo. The glissando pattern appears beginning with bar 3 with a long held vocal position, illustrating the message that the composer wishes to convey. 


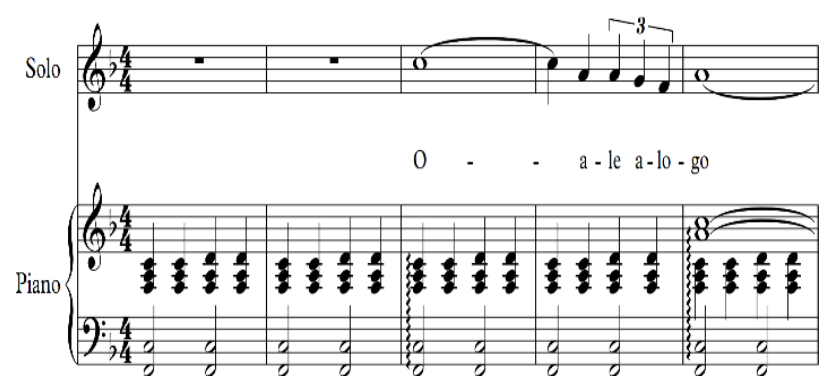

Figure 2. "O Ale Alogo" (Bar 1-5)

The accompaniment pattern with homophonic texture by playing harmony on the right hand is maintained throughout the work. It's just that, in part B (development) suddenly, Cornel does modulation (up $3 \mathrm{~m}$ or A-flat major) as repetition of material A. This is done to give emphasis to the message to be conveyed.

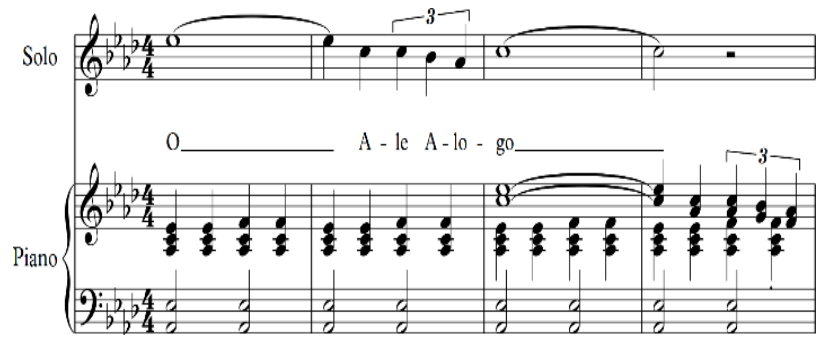

Figure 3. Modulation in part B -" Ale Alogo"

In general, the vocal line "O Ale Alogo" is marked by the following variables; (1) only one note per syllable; (2) several syllables chanted in a row; (3) melodies use small intervals; (4) notes are sung legato; and (5) the use of articulation, especially accents for certain parts only.

The piano accompaniment's role is to support the singer with harmonious development and other forms of melody, all in several different types of textures. The "O Ale Alogo" accompaniment also has several distinctive characteristics, including; (1) simple chords; (2) simple chords are broken down into repetitive rhythmic patterns; (3) homophonic texture; (4) glissando to support waves of sea water; and (5) articulation in several parts to support the movement of vocal expression. A more complex relationship between vocal 
lines and accompaniment occurs when the accompaniment has a more dominant melodic component. In the composition "O Ale Alogo", the right hand doubles the vocal line and does not offer a counter melody to the vocal line.

\section{Recommendations}

First, the discourse on seriosa learning in universities in Indonesia needs to be accompanied by a study of poetry, because after all, poetry is an inseparable part of seriosa. Second, the expression and interpretation of the seriosa singer must not only focus on the notation, because text becomes important to convey messages through various metaphors. Understanding the metaphors in the text will certainly help the singer to be able to actualize them in the show.

\section{References}

Agawu, V. Kofi. (1991). Playing with Signs: A Semiotic Interpretation of Classic, Music. Princeton: Princeton University Press.

Apel, Willi. (1969). Harvad Dictionary of Music. The Belknap Press of Harvad University Press, Cambridge, Massachusetts, pp. 729.

Bennett, Joseph. The Poetic Basis of Music. The Musical Times and Singing Class Circular, Vol. 16, No. 373 (Mar. 1, 1874), pp. 411-414.

Cook, Nicholas. (1987). A Guide to Musical Analysis. New York: Braziller.

Field, Kate C. The Poetic Basis. The Musical Times and Singing Class Circular, Vol. 16, No. 375 (May 1, 1874), pp. 492-493.

Manalu, Kartini, R.M. (2014). Analisis Komposisi dan Teknik Bernyanyi Seriosa Indonesia. Thesis - Program Studi Penciptaan dan Pengkajian Seni Universitas Sumatera Utara.

Meyer, Leonard B. (1956). Emotion and Meaning in Music. Chicago: University of Chicago Press.

Mohammed, Sharifah Faizah Syed. (2016). "The History and Development of Lagu 
Seriosa in the Context of Musical Nationalism in Indonesia". Dissertation - Doctor of Philosophy at Monash University.

Nattiez, Jean-Jacques. (1990). Music and Discourse: Toward a Semiology of Music. Translated by Carolyn Abbate. Princeton: Princeton University Press.

Simanjuntak, Hendrik L. (2014). Struktur Musik Movement Finale Simfoni Kesembilan Beethoven. Majalah Visi; Vol.20, Oktober 2012, pp. 1145-1164.

Simanjuntak, Hendrik L. (2018). "Desain Gerakan Finale Simfoni Kesembilan Beethoven", (Eds.) Andre Idrawan, dalam Berbagi Musik Persembahan Untuk Sang Maha Guru. BP ISI Yogyakarta, pp. 59-70.

Tjaroko, Winarjo Sigro. (2007). "Sejarah Perkembangan Lagu Seriosa Indonesia”. Thesis - Program Studi Pengkajian Seni Pertunjukan dan Seni Rupa Universitas Gadjah Mada Yogyakarta.

Tuutau, Daniel. (2015). “Tembang Puitik: Ananda Sukarlan and the Current State of Indonesian Classical Vocal Music". Dissertation - Doctor of Musical Arts in Vocal Performance School of Music, University of Utah.

Yunita, Ayu Tresna. (2012). "Kebangkitan Nasionalisme Eropa dan Pengaruhnya Terhadap Perkembangan Lagu Seriosa Indonesia", Thesis - Program Studi Pengkajian Seni Pertunjukan dan Seni Rupa Universitas Gadjah Mada Yogyakarta, Universitas Gadjah Mada.

Webster, James. (1991) Haydn's "Farewell” Symphony and the Idea of Classical Style. Cambridge: Cambridge University Press.

Webster, James. "Schubert's Sonata Form and Brahms's First Maturity." 19th Century Music 2, 1978, pp. 18-35. 